\title{
LIQUIDITY MANAGEMENT AND FINANCIAL PERFORMANCE OF LISTED OIL AND GAS COMPANIES IN NIGERIA
}

\author{
Ismail Alhassan \\ Senior Lecturer \\ Department of Accounting \\ School of Business Education \\ Federal College of Education (Technical) \\ Gombe, Gombe State, Nigeria \\ E-mail: ismailalhassan@fcetgombe.edu.ng \\ K. M. Anwarul Islam \\ Associate Professor \\ Department of Business Administration \\ The Millennium University, Dhaka, Bangladesh \\ E-mail: anwarul@themillenniumuniversity.edu.bd
}

Received: August 26, 2021 Accepted: September 06, 2021 Online Published: September 29, 2021

DOI: 10.46281/ijafr.v8i1.1364

URL: https://doi.org/10.46281/ijafr.v8i1.1364

\begin{abstract}
The purpose of this paper is to figure out the link between liquidity and profitability, as well as the impact of liquidity on profitability. Ten listed companies with a bigger market share in the oil and gas sector of the Nigerian economy were subjected to a fixed panel regression study. Secondary data was gathered for ten years, from 2011 to 2020, from their published annual reports. Profit after tax (PAT), Return on Asset (ROA), and Return on Equity (ROE) were used to determine profitability (ROE). Internal liquidity variables such as equity, debt, and sales were utilized to determine the behavior of the dependent variable, but external elements such as lending interest rate and exchange rate were employed to further explain profitability behavior. The data were analyzed using a multiple regression approach. The findings reveal that debt has a significant negative impact on companies' profitability. Similarly, equity capital, as well as retained earnings, are more beneficial to firms than the debt financing of the oil and gas sector. The study, therefore, recommends that oil and gas firms should boost their equity capital, improve their revenues, increase their retain earnings, and reduce debt financing to enable them to generate more wealth for shareholders.
\end{abstract}

Keywords: Liquidity Management, Financial Performance, Oil and Gas Sector.

JEL Classification Codes: F65.

\section{INTRODUCTION}

In an economy where financial institutions are reluctant to extend credit facilities (loans) due to an increase in non-performing loans and high-interest rates on loans, the concept of liquidity and its management is extremely important, especially in this period of global financial disruption, to be thoroughly examined and taken seriously. 
Liquidity management is a critical component of any organizational environment that necessitates careful consideration, planning, and management because it influences the level of trust among stakeholders. Liquidity should be controlled such that neither too much nor too little is available as firms with poor liquidity management experience illiquidity and eventually bankruptcy (Majakusi, 2016; Abdi \& Kavale, 2016; Edem, 2017). The need for shareholders to maximize their wealth has forced the primary goal of profit maximization for businesses. Firms' capital structures, however, are made up of debt and equity, which refers to borrowed funds and owned assets, respectively (Umobong, 2015). A company's debt portfolio is mostly made up of short- and long-term obligations that can only be paid if liquidity is available. Liquidity has been defined in this context as the ease with which assets can be converted into cash and cash equivalents with minimal loss in value. The opportunity cost of remaining liquid is the loss of earnings from not investing in higher-yielding assets.

According to Salim and Bilal (2016), a firm's capital structure is determined by its liquidity level or position. The ability of the company to satisfy its long- and short-term obligations in good times and bad, as a result of changing economic conditions, is what all investors and creditors are concerned about. The ideal amount of liquidity that a firm must maintain in order to attain a specific level of profitability varies from one firm to the next because there is no set rule for determining the optimal level of liquidity that a firm must maintain.

The Nigerian economy entered a technical recession in the second quarter of 2016, leaving indigenous companies, particularly oil and gas companies, vulnerable to existential threats due to cash concerns. Due to the ongoing rise in bank non-performing loans, financial institutions are hesitant to extend credit to businesses. This could be due to the recent oil price shock (a sharp drop in the price of oil), which had a significant impact on banks with exposure to the oil and gas sector. In addition, the Nigerian economy has seen an increase in inflation and a chronic depreciation of the currency Kung'u (2017). As a result, credit/loan extensions are unlikely during periods of rising inflation, emphasizing the significance of good and efficient liquidity management to meet a firm's obligations while also being profitable. The next question is: what is the ideal level of liquidity that should be accessible in order to sustain the appropriate level of profitability? What effect does liquidity have on a company's performance? The study's goal is to evaluate the optimal degree of liquidity and its impact on company performance and profitability, particularly in the oil and gas industry. This is justified by the recent drop in oil prices, which is one of the primary factors that has "piloted" the Nigerian economy into recession. Being an oil dependent nation, the health of the Nigerian economy is largely determined by the oil and gas sector's liquidity and profitability management, Patrick (2018). This study covers a period of ten years from 2011-2020.

\section{Conceptual Review}

\section{LITERATURE REVIEW}

Liquidity refers to a person's or organization's ability to satisfy immediate and long-term requirements using cash or assets that can be easily transformed into cash. Investors may also define liquidity as the capacity to turn an investment portfolio into cash rapidly and with little or no loss of value. All of these concepts are critical to a company's success since a firm's understanding of liquidity and how to manage it ensures the company's survival, even as a stakeholder.

In their research, some scholars have attempted to define the term liquidity and its significance in any corporate organization. Financial liquidity is a complex but critical concept that defines the soundness and stability of the financial system. Because capital is essential at the start of any business, this emphasizes the relevance of liquidity not only to the financial system but to all industries. Liquidity was defined in terms of 'flows,' that is, unrestricted flows among financial system and market players, as well as the ability to realize these flows.

Most business failures in the past have been attributed to business owners' incapacity to properly manage their firms' liquidity, ensuring profitability. Ehiedu (2014) argued that liquidity should not be excessive or insufficient. Excess liquidity refers to accumulated idle cash that does not generate profit for the firm or organization, whereas insufficient liquidity would affect the firm's manufacturing process, 
earning ability, and creditworthiness. Liquidity ratios apply to a number of different liquidity indicators, including net working capital, cash ratio, quick ratio, and current ratio, to name a few. A low ratio suggests that the corporation or firm is experiencing financial difficulties or is managing its liquidity poorly. A high ratio also suggests that the company is in good financial shape, but it should not be too high because extra funds have a high opportunity cost. Because of their interest in the firm's day-to-day activities, both external and internal analysts value liquidity management. According to Raheman and Nasr (2007), the dilemma in liquidity management is deciding how to achieve the required trade-off between liquidity and profitability. Gaining more of one results in a loss of the other.

A company's principal goal and objective are to maximize profit in order to meet shareholder expectations for dividend payments. Simply put, profitability refers to a company's capacity to make a profit. Many factors have been identified as affecting a firm's profitability, including the degree of competition it faces, the size of the firm, and so on. However, according to this study, the management of liquidity has been identified by many researchers as one of, if not the most important factor affecting profitability.

Because of the large proportion of non-performing loans in their portfolios, most banks are in trouble today. This emphasizes the importance of liquidity management in defining a company's level of profitability as well as maintaining the company's viability.

\section{Theoretical Review}

Numerous theories have been proposed to explain the impact of liquidity on company profitability. Theories of capital structure will be addressed in connection to liquidity management and its impact on profitability in this study. After Modigliani and Miller (1959) argued that capital structure is immaterial in determining a firm's profitability under ideal market conditions, capital structure theories became prominent. A company's capital structure consists of its stock and debt to achieve its goals. For businesses, determining the best capital structure to minimize capital costs while maximizing value remains a challenge. This research assumes that a company's capital structure impacts its liquidity levels and situations. The following theories are considered in light of this:

\section{Pecking Order Theory}

In the face of knowledge asymmetry in the source of finance, the Pecking Order Theory of Capital Structure illustrates how managers might lower inefficiencies. The studies of Myers and Majluf are said to have influenced the development of the Pecking Order idea in 1984. Their hypothesis, however, was centered on Donaldson's belief that what motivates a management financing policy is their aspirations, which lead to financial decisions targeted at decreasing organizational mismanagement based on information asymmetry. Companies will choose a less expensive form of financing because management is also concerned about maximizing profit. According to the structure of the pecking order theory, a company's retained earnings are used first, then debt is issued, and finally, equity is issued as a last resort. The study by Titman and Wessels (1988) reveals that more lucrative enterprises will require less external finance, supporting the pecking order idea. According to Frank and Goyel (2003), larger organizations have an easier time deciding on the optimal source of finance than smaller firms.

\section{Trade-off Theory}

The trade-off theory of capital structure proposes that a corporation decides how much debt and equity financing to utilize by weighing the costs and advantages. The fundamental form of the idea was provided by Kraus and Lichtenberger, who suggested a way to balance the expenses of bankruptcy with the tax savings of the debt. Frank \& Goyel present a survey of the literature for this idea, which is often set up as a competitor hypothesis to the pecking order theory of capital structure. Firms finance their activities using a combination of debt and equity, according to the trade-off theory. It shows how debt financing has both advantages and disadvantages. Tax benefits are obtained, but the company is also vulnerable to the expenses of financial difficulty, which include both bankruptcy and non-bankruptcy 
debt obligations. The trade-off hypothesis also explains why accumulating more debt puts investors' and shareholders' financial standing in jeopardy.

According to Owolabi and Obida (2012), trade-off theory argues that enterprises want to keep their liquidity levels at a level that balances the benefits and costs of keeping liquidity. A lower rate of return, as well as a tax disadvantage, are included in this expense. Nonetheless, keeping cash on hand protects assets from being liquidated in order to meet commitments. Liquid assets, according to Umobong (2015), can be utilized to finance a company's operations as well as other companies' investments if capital is unavailable. A lower rate of return, as well as a tax disadvantage, are included in this expense. Nonetheless, keeping cash at hand protects assets from being liquidated in order to meet commitments. Liquid assets, according to Umobong (2015), can be utilized to finance a company's operations as well as other companies' investments if capital is unavailable. A lower rate of return, as well as a tax disadvantage, are included in this expense. Nonetheless, keeping cash at hand protects assets from being liquidated in order to meet commitments. Liquid assets, according to Umobong (2015), can be utilized to finance a company's operations as well as other companies' investments if capital is inaccessible.

\section{Net Income Theory (NIT)}

The net income theory outlines how leverage affects a company's capital structure. It implies that a company's profitability can be increased by raising leverage and lowering the overall cost of capital. When it comes to growing a company's worth, NIT advocates debt financing rather than equity financing. Debt interest is tax-deductible, hence debt financing is less expensive than equity financing. Increased debt finance, on the other hand, may increase the chance of bankruptcy. Because of the unrealistic position of Modigliani and Miller (1959), that financial leverage does not affect the capital structure of the organization, he bases his arguments on various assumptions that are not true in reality. Due to the tax shelter gained when taxes are paid on time, Modigliani and Miller (1963) proposed that enterprises should use more debt to increase value. Capital structure, in his opinion, is determined by tax benefits that lower the cost of capital. Orshi (2016) counters that a company should maintain an ideal debt-to-equity ratio because concentrating more on the debt will increase the cost of capital due to the market's demand for a higher rate of return. Dzapasi (2020) agreed with Solomon, stating that it is usual for creditors to seek a higher rate of return on borrowed funds as companies borrow more. As a result, the company may face insolvency and default on its obligations. As a result, organizations will aim to reduce the risk of bankruptcy, which necessitates determining an ideal level at which value is maximized and costs are minimized.

\section{Net Operating Income Theory}

In the face of knowledge asymmetry in the source of finance, the Pecking Order Theory of Capital Structure illustrates how managers might reduce inefficiencies. The studies of Myers and Majluf are said to have influenced the development of the Pecking Order idea in 1984). Their hypothesis, however, was founded on Patjoshi (2016) belief that what motivates a management finance policy is their expectations, which lead to financial actions targeted at minimizing organizational inefficiencies based on information asymmetry. Companies will choose a less expensive method of financing because management is also concerned about maximizing profit. According to the hierarchy of the pecking order theory, a company's retained earnings are used first, then debt is issued, and finally, equity is issued as a last resort. The study by Patjoshi (2016) reveals that more lucrative enterprises will require less external finance, supporting the pecking order idea. According to Frank \& Goyel (2003), larger organizations have an easier time deciding on the optimal source of finance than smaller firms.

\section{Empirical Review of Prior Studies}

Oladipupo and Okafor (2013) examined the impact of working capital management on a company's profitability. Using the net trade ratio, current ratio, debt ratio, and sales growth as measures of working capital during five years, it was discovered that there is no association between profitability and working 
capital at a level of 5\%. He went on to say that increasing leverage resulted in a drop in profitability. Due to the inverse link between liquidity and profitability, this could be the case. However, an increase in leverage does not necessarily imply a decrease in profitability because the borrowed funds are invested, generating returns over time, but in the long run, a persistent growth in debt financing may result in a decrease in the firm's profitability. Return on asset is only affected by the liquid ratio, but the return on investment is affected by the current ratio, quick ratio, and liquid ratio of Pakistani oil and gas businesses, according to Saleem and Rehman (2011). Meanwhile, none of the liquidity measures had an impact on return on equity. Liquidity ratios have an impact on profitability, as evidenced by the study findings.

Credit policies, cash flow management, and the cash conversion cycle were measured by Owolabi and Obida (2012), who discovered that they have a considerable influence on the earnings of industrial companies quoted on the Nigerian stock exchange. Return on asset is only affected by the liquid ratio, but the return on investment is affected by the current ratio, quick ratio, and liquid ratio of Pakistani oil and gas businesses, according to Saleem and Rehman (2011). Meanwhile, none of the liquidity measures had an impact on return on equity. Liquidity ratios have an impact on profitability, as evidenced by this. Credit policies, cash flow management, and the cash conversion cycle were measured by Owolabi and Obida (2012), who discovered that they have a considerable influence on the earnings of industrial companies quoted on the Nigerian stock exchange. The cash conversion cycle (CCC) is a metric that quantifies the duration between cash payments for inventory purchases and the recovery of receivables from consumers.

Ben-Caleb et al. (2013), on the other hand, found that CCC is inversely correlated to manufacturing company profitability in Nigeria. The current ratio and liquidity ratio are strongly tied to manufacturing company profitability, according to his sample of 30 manufacturing companies listed on the NSE from 2006 to 2010. This explains why liquidity has such a minor impact on profitability. The relevance of liquidity management on profitability was investigated by Bhunia and Brahma (2011). The results reveal that there is a positive significant association between liquidity and profitability in the steel business from 1997 to 2006.

Njue (2020) observed that enterprises use more short-term debt financing in their operations when analyzing the effect of capital structure on the profitability of Ghanaian listed firms. The study discovered that short-term debt is a significant source of funding for businesses. In the quest for profit maximization, the basis of liquidity is critical, yet most businesses struggle to discover the appropriate amount that will minimize costs while maximizing advantages. The ideal capital structure maximizes the market value of the firm's outstanding shares. According to Padachi (2006), a manager's job is to strike a balance between preserving liquidity and creating a profit while running a company's business operations.

\section{Data Source}

\section{METHODOLOGY}

The financial statements of ten companies in the oil and gas sector of the Nigerian economy were accessible, and the main indicators for this research were computed using information from their annual reports. The association between liquidity and profitability is discovered using the multiple regression method.

\section{Model Specification and Estimation Techniques}

The model's specification is built on capital structure theories, particularly the net income and net operating income theories. On this foundation, this study looks at how equity, debt, and sales as internal metrics of liquidity can best explain profitability behavior. This research also looks at external drivers of company performance, proposing that some macroeconomic variables, which can be regarded as external shocks, affect company performance, such as the lending interest rate. Fixed effect panel regression was used in this study because fixed effect panel regression is deemed to be suitable for the study after conducting the "Hausman" test. The second reason for using fixed effects is that they adjust 
for time-invariant features among the chosen firms, which indicates why the estimated coefficients of fixed-effects models cannot readily be skewed by omitted time-invariant variables. To further reflect the variable of interest, the study used three equations that were letter combined into one. As a result of the foregoing claim, the model is as follows. The implicit form:

$$
\text { pat }=f(\text { roe }, \text { roa }, e q, d b, \text { sls }, \text { lir })
$$

The explicit form of the above equation is shown in equation (2)

$$
\begin{aligned}
& P A T_{i t}=\beta o+\beta_{1 i t} r o e+\beta_{2 r o a t}+\beta_{3 e q} q_{i t}+\beta_{4} d b_{i t}+\beta_{5 s l} s_{i t}+\beta_{6} l i r i t_{i t}+\mu_{i t} \\
& R_{\text {OEit }}=\alpha O+\alpha_{1} \text { roa }_{i t}+\alpha_{2} e q_{i t}+\alpha_{3} d b_{i t}+\alpha_{4} \text { sls }_{i t}+\alpha_{5} l_{i r_{i t}}+\mu_{i t} \\
& R O A i t=\gamma O+\gamma_{1} e q_{i t}+\gamma_{2} d b_{i t}+\gamma_{3} s_{\text {lit }}+\gamma_{5} l i r_{i t}+\mu_{i t}
\end{aligned}
$$

Merging equations 2, 3, and 4 to better capture the profitability of firms, yields the implicit form of:

$$
p f=f(e q, d b, s l s, l i r)
$$

Using the lag it gives:

$\Delta \mathrm{pf}^{\mathrm{K}}{ }_{\mathrm{it}}=\beta_{0},+\sum_{\mathrm{t}=1}^{\mathrm{n}} \beta_{1} \Delta \mathrm{es}_{\mathrm{it}-1}+\sum_{\mathrm{t}=0}^{\mathrm{n}} \beta_{2} \Delta \mathrm{db}_{\mathrm{it}-1}+\sum_{\mathrm{t}=0}^{\mathrm{n}} \beta_{3} \Delta \mathrm{sl}_{\mathrm{it}-1}+\sum_{\mathrm{t}=0}^{\mathrm{n}} \beta_{4} \Delta \mathrm{lir}_{\mathrm{it}-1}+\dot{\alpha} \mathrm{i}+\mathrm{u}_{\mathrm{it}-1}-(2)$

Equation (1) above can be presented as:

$p f_{i t}=\beta_{0}+\beta_{1} e q_{i t}+\beta_{2} d b_{i t}+\beta_{3} s l s_{i t}+\beta_{4} l i r_{i t}+u_{i t}$

Equation (2) is now been transformed into a logarithm to bring it to a more harmonious form as:

$$
p f_{i t}=\text { Aeqit }^{\beta 1}{ }^{d b_{\beta 2 i t}} \text { slsit }^{\beta 3}{\text { lirit } \beta 4 u_{i t}}
$$

Given the logarithm conversion of the variables, but holding debt and lending interest rate constant in their natural state equation (3),

It is linearized as:

$$
p f_{i t}=\beta_{0}+\beta_{1 \log } e q_{i t}+\beta_{2} d b_{i t}+\beta_{3 \log } s l s_{i t}+\beta_{2} l i r_{i t}+u_{i t}
$$

$\mathrm{H}_{0}: \quad \beta_{1}=\beta_{2}=\beta_{3}=\beta 4=0$

$\mathrm{H}_{1}: \quad \beta_{1} \neq \beta_{2} \neq \beta 3 \neq \beta 4 \neq 0$

\section{Where}

Pf - firm profitability (the endogenous variable): the fundamental goal of any firm is to make money; any other goal is considered secondary. Because time spent by the owners in coordinating the operations of the business could be utilized in managing other enterprises, firms' profitability could be said to represent an opportunity cost (opportunity cost) (Dixon, 1990). Three main performance variances (K=3, as indicated in equation 3) were used to properly represent organizations' profitability in this study: return on assets (ROA), return on equity (ROE), and profit after tax (PAT) (PAT): 
The proportion at which a company makes a profit in relation to its assets is captured by the ROA, which provides insight into the firm's or firm's efficiency. This is computed as the ratio of a company's net income to its total profit (Net income/Total Assets); similarly, return on equity (ROE $=\mathrm{NY} / \mathrm{ES}$ ) evaluates the actual sum of a company's net income returned as a proportion of its shareholders' equity. The amount of money left over after taxes is referred to as the firm's disposable income. To represent the firm's performance, the three variables were pooled and their averages were taken. Where delta $(\Delta)$ represents the potential for endogenous or external shocks to cause changes.

EQ - In layman's terms, equity refers to a bank's ownership interest. The capital structure of a bank is made up of equity, which is defined as asset minus obligation.

DB - Debt refers to monies borrowed by a company to fund its operations, often known as leverage financing. Short-term and long-term obligations come from banks in the form of loans and grants, companies in the form of credits, and the general public in the form of common stock and bond sales. As a result, debts create responsibility responsibilities that must be met in the course of doing business.

SLS - Sales is the exchange of goods and services for a monetary value or equivalent

LIR stands for lending interest rate, which is the interest rate at which banks lend money to consumers in the form of loans and advances. According to the World Bank's world data indicators, Nigeria's loan interest rate was 16 percent in 2015.

0 is the constant term, 1, 2, and 3 are the exogenous coefficients, and I is the entity-time invariant of the selected organization. Assuming that the model employs a double log (i.e logging both sides of the equation - the endogenous and endogenous variable), time indicates the time required to achieve a certain level of profit, and log represents the logarithm transformation of the variables.

$\mathbf{u}$-the error term that is expected to be id $\mathrm{N}(0, \sigma 2)$.

The appropriate expectation is that $\alpha_{i}>, \mathrm{i}=1,2,3 \& 5>0$, while $4<0$. Hence, a rise in the explanatory variables (except debt) is anticipated to improve profitability rates, ceteris paribus.

\section{DESCRIPTIVE ANALYSIS}

This paper offers and analyses data used as indicators for the effects of liquidity on firm profitability in the Nigerian oil and gas sector, which includes exogenous factors such as debt, equity, lending interest rates, and sales as measures of liquidity. While endogenous variables such as return on equity (ROE), return on assets (ROA), and profit after tax (PAT) serve as proxies for profitability. Table 4.1 summarizes the findings of the descriptive analysis.

Table 1. Summary Statistics of Variables

\begin{tabular}{|l|l|l|l|l|}
\hline Variable & Mean & Standard Deviation & Minimum & Maximum \\
\hline Lpf & 12.6022 & 1.42109 & 8.3227 & 16.3123 \\
\hline Equity & 16.7781 & 2.23432 & 10.7341 & 22.4744 \\
\hline Sales & 17.2417 & 1.21121 & 15.9311 & 21.7256 \\
\hline Debt & 7.3603 & 2.43208 & 3.7701 & 14.1008 \\
\hline Interest rate & 14.6873 & 0.53192 & 10.1649 & 17.5183 \\
\hline
\end{tabular}

Source: Researcher's Computation using STATA 16 
Table 1 shows the variable's statistical results. Firm profitability is determined by the variables chosen. Firm profitability is determined by Return on Assets (ROA), Return on Equity (ROE), and Profit after Tax (PAT), all of which are heavily influenced by debt. Debt is a type of liability for oil and gas companies that tends to diminish profit margins. In conjunction with the Net Income Theory, which explains why people prefer debt over equity, it also explains why having too much debt can lead to a high likelihood of bankruptcy and a high probability of default in shareholder settlements. As a result of the significant risk exposure, shareholders demand a significant dividend. Due to its near to zero, the loan interest rate, with a standard deviation of around 0.5 , is less volatile than other variables, as shown in table 1 . With a standard deviation of 2.4 , debt is more volatile than other variables.

Table 2. Correlation Matrix of variables

\begin{tabular}{|l|lll|ll|}
\hline & lpf & les & Isl & db & lir \\
\hline Lpf & 1.0000 & & & & \\
\hline Equity & 0.1242 & 1.0200 & & & \\
\hline Sales & 0.2315 & 0.2387 & 1.0500 & & \\
\hline Debt & 0.3187 & 0.3582 & 0.1226 & 1.2700 & \\
\hline Interest rate & 0.0123 & -0.0162 & -0.0450 & -0.0211 & 1.0543 \\
\hline
\end{tabular}

\section{Source: Authors' Computation using stata 16}

Table 2 shows that the variables have no occurrence of multicollinearity because their levels are quite low, indicating that the model is well fitted.

The fixed panel regression results are displayed below. The "Hausman Test" was used to justify the usage of this strategy. The Hausman test proved that the fixed effect method is the best alternative. As a result, Table 3 shows the outcome.

Table 3. Result from the fixed panel regression

\begin{tabular}{|l|l|l|l|l|}
\hline Lpf & Coefficient & $\begin{array}{l}\text { Standard } \\
\text { Error }\end{array}$ & t-statistic & P>t \\
\hline Equity & 1.20123 & 0.10219 & 11.26 & 0.010 \\
\hline Sales & 2.46015 & 0.32319 & 4.25 & 0.021 \\
\hline Debt & -1.3708 & 5.61609 & -3.95 & 0.010 \\
\hline Interest rate & 0.38101 & 0.21682 & 2.51 & 0.151 \\
\hline cons & -40.0101 & 12.3196 & -3.09 & 0.001 \\
\hline \hline
\end{tabular}

Source: Authors' Computation using Stata 16

Table 3 shows the regression analysis results, Beginning with equity, it can be determined that a percentage change in equity results in a more than commensurate change in the level of profitability by 120 percent on average, indicating that it is elastic. As a consequence of the t-statistic and probability value derived, equity has a significant impact on the level of profitability. Other factors (sales and lending interest rates) fall into line since an improvement in a firm's sales volume and a bank's lending rate of interest will necessarily enhance a firm's profitability, confirming the "a priori" forecast. That a relative sales volume among firms over time tends to result in a bigger proportional gain in profit. Increases in bank lending interest rates to businesses will deter businesses from borrowing due to the high rate. As a result, lowering borrowing/leverage financing may raise the chance of bankruptcy. As a result, this study has demonstrated that debt is a crucial element affecting a company's profitability, as 
well as the necessity for greater equity financing over debt financing. As a result, the company can reduce debt by growing revenues. According to the aforementioned estimate, a 2.4 percent improvement in profitability will result from a unit change in sales. This can be accomplished by increasing oil prices, increasing market concentration, which enhances the possibility for abnormal profits due to monopolistic advantage, and lowering costs through economies of scale. Debt restructuring also allows businesses to minimize their debt burdens by refinancing outstanding debt at a cheaper interest rate. The findings of this study concur with that of Otekunrin et al. (2019), Mwangudza, Jagongo, and Ndede (2020) as well as that of Sathyamoorthi, Mapharing, and Dzimiri (2020). However, it does not concur with the studies of Song'e (2015) and Njeru (2016).

Effective and efficient inventory management can also help businesses reduce debt by preventing cash flow waste. Product diversification by enterprises, suitable and increased awareness creations, and acceptable price levels, on the other hand, can all help to boost sales.

\section{CONCLUSION AND RECOMMENDATIONS}

This study addresses the issue of obtaining funding from the financial sector during periods of economic downturn. Because of the drop in oil prices, the ongoing high inflation, and the depreciation of the Naira versus the dollar, effective liquidity management is critical to the oil and gas sector's viability following Nigeria's oil dependency.

The results obtained from the study explains the primacy of equity financing over debt financing in the Nigerian oil and gas sector's capital structure. With a percentage rise in equity, profitability is said to rise by more than 120 percent, resulting in improved performance. Debt financing, on the other side, affects business profitability by over 150 percent, lowering the performance of firms in the oil and gas sector of the economy. Increased actions to encourage product sales will boost performance by 2.4 percent, while discouraging debt financing with higher loan interest rates will boost profitability by 38 percent, according to the study.

As a result, this analysis suggests that financing investment through a company's retained earnings and equity is both cheaper and safer. This is in line with the pecking order theory and the net operating income theory, which place a greater focus on a company's operational income than leverage, which raises the danger of bankruptcy. Therefore, in light of Nigeria's recent economic distress, effective liquidity management is critical for businesses, as reliance on bank loans may not be sustainable due to the increase in banks' non-performing loans as a result of the recent drop in oil prices.

\section{REFERENCES}

Abdi, A., \& Kavale, S. (2016). Effect of liquidity management on financial Perfomance of commercial banks in mogadishu, somalia. International Journal for Research in Business, Management and Accounting, 2(5), 101-123.

Ben-Caleb, E., Olubukunola, U., \& Uwuigbe, U. (2013). Liquidity management and profitability of manufacturing companies in Nigeria. IOSR Journal of Business and Management, 9(1), 13-21.

Bhunia, A., \& Brahma, S. B. (2011). Importance of Liquidity Management on Profitability. Asian Journal of Business Management, 3(2), 108-117.

Dzapasi, F. D. (2020). The impact of Liquidity Management on Bank Financial Performance in a subdued economic environment: A case of the Zimbabwean Banking Industry. PM World Journal, 9(1), 1-20.

Ehiedu, V. C. (2014). The impact of liquidity on profitability of some selected companies: The financial statement analysis (FSA) approach. Research Journal of Finance and Accounting, 5(5), 81-90.

Edem, D. B. (2017). Liquidity management and performance of deposit money banks in Nigeria (1986- 
2011): An investigation. International Journal of Economics, Finance and Management Sciences, 5(3), 146-161.

Frank, M. Z., \& Goyal, V. K. (2003). Testing the pecking order theory of capital structure. Journal of financial economics, 67(2), 217-248.

Kung'u, J. (2017). Effect of liquidity management practices on profitability of manufacturing industry in Kenya. IOSR Journal of Economics and Finance, 8(1), 84-89.

Majakusi, J. (2016). Effect of Liquidity management on the financial performance of commercial banks in Kenya (Doctoral dissertation, University of Nairobi).

Modigliani, F., \& Miller, M. H. (1959). The cost of capital, corporation finance, and the theory of investment: Reply. The American Economic Review, 49(4), 655-669.

Modigliani, F., \& Miller, M. H. (1963). Corporate income taxes and the cost of capital: a correction. The American economic review, 53(3), 433-443.

Mwangudza, C. K., Jagongo, A., \& Ndede, F. W. (2020). Liquidity Management and Financial Performance of Teachers Deposit Taking Savings and Credit Cooperative Societies in Kenya. International Journal of Finance and Accounting, 5(2), 1-26.

Njeru, M. D. (2016). Effect of Liquidity Management on financial performance of Deposit Taking Saving and credit co-operative society in Kenya (Doctoral dissertation, Business Administration (Finance), JKUAT).

Njue, A. (2020). Liquidity Management and Financial Performance of Microfinance Institutions in Kenya (Doctoral dissertation, University of Embu).

Oladipupo, A. O., \& Okafor, C. A. (2013). Relative contribution of working capital management to corporate profitability and dividend payout ratio: Evidence from Nigeria. International Journal of Business and Finance Research, 3(2), 11-20.

Orshi, T. S. (2016). Impact of liquidity management on the financial performance of listed food and beverages companies in Nigeria. Published Thesis, Federal University Dutsin-Ma.

Otekunrin, A. O., Fagboro, G. A., Nwanji, T. I., Asamu, F., Ajiboye, B. O., \& Falaye, A. J. (2019). Performance of deposit money banks and liquidity management in Nigeria. Banks and Bank Systems, 14(3), 152-161.

Owolabi, S. A., \& Obida, S. S. (2012). Liquidity management and corporate profitability: Case study of selected manufacturing companies listed on the Nigerian stock exchange. Business Management Dynamics, 2(2), 10-25.

Padachi, K. (2006). Trends in working capital management and its impact on firms' performance: an analysis of Mauritian small manufacturing firms. International Review of business research papers, 2(2), 45-58.

Patjoshi, P. K. (2016). A Study on Liquidity Management and Financial Performance of Selected Steel Companies in India. International Journal of Advanced Information Science and Technology, 5(7), 108-117. 
Patrick, O. (2018). Impact of liquidity management on the performance of insurance companies in Nigeria. Journal of Economics and Finance, 9(1), 40-45.

Raheman, A., \& Nasr, M. (2007). Working capital management and profitability-case of Pakistani firms. International review of business research papers, 3(1), 279-300.

Salim, B. F., \& Bilal, Z. O. (2016). The impact of liquidity management on financial performance in Omani banking sector. International Journal of Accounting, Business and Economic Research, 14(1), 545-565.

Saleem, Q., \& Rehman, R. (2011). Impacts of liquidity ratios on profitability, interdisciplinary. Journal of Research in Business, 1(7), 78-91.

Sathyamoorthi, C. R., Mapharing, M., \& Dzimiri, M. (2020). Liquidity Management and Financial Performance: Evidence From Commercial Banks in Botswana. International Journal of Financial Research, 11(5), 399-413.

Song'e, H. K. (2015). The effect of liquidity management on the financial performance of deposit taking Saccos in Nairobi (Doctoral dissertation, University of Nairobi).

Titman, S., \& Wessels, R. (1988). The determinants of capital structure choice. The Journal of finance, 43(1), 1-19.

Umobong, A. A. (2015). Assessing the impact of liquidity and profitability ratios on growth of profits in pharmaceutical firms in Nigeria. European Journal of Accounting, Auditing and Finance Research, 3(10), 97-114.

\section{Copyrights}

Copyright for this article is retained by the author(s), with first publication rights granted to the journal. This is an open-access article distributed under the terms and conditions of the Creative Commons Attribution license (https://creativecommons.org/licenses/by/4.0). 